\title{
Erratum to: A New Deep-Sea Suctorian-Nematode Epibiosis (Loricophrya-Tricoma) from the Blanes Submarine Canyon (NW Mediterranean)
}

\author{
Gregorio Fernandez-Leborans ${ }^{1} \cdot$ Sara Román $^{2} \cdot$ Daniel Martin $^{2}$
}

Published online: 6 June 2017

(C) Springer Science+Business Media New York 2017

Erratum to: Microb Ecol (2016)

DOI 10.1007/s00248-016-0923-5

The original version of this article unfortunately contains missing data. These are the access numbers from the Musseum für Naturkunde (Berlin, Germany) for the epibiont species Loricophrya mediterranea n. sp.: ZMB Protoz 64 for slide 1 (parahapantotype) and ZMB Protoz 65 for slide 2 (hapantotype).

The online version of the original article can be found at http://dx.doi. org/10.1007/s00248-016-0923-5

\footnotetext{
Gregorio Fernandez-Leborans

greg@bio.ucm.es
}

1 Departamento de Zoología, Facultad de Biología, Universidad Complutense de Madrid, C/ José Antonio Novais, 12, 28040 Madrid, Spain

2 Department d'Ecologia Marina, Centre d'Estudis Avançats de Blanes, CEAB-CSIC, C/ Accés a la cala St Francesc, 14,

17300 Blanes (Girona), Catalunya, Spain 